\title{
Which governance structures drive economic, environmental, and social upgrading? A quantitative analysis in the assembly industries
}

\author{
Ruggero Golini* \\ Università degli Studi di Bergamo, Department of Management, Information and \\ Production Engineering, Via Pasubio, 7, 24044 Dalmine (BG), Italy \\ Valentina De Marchi \\ University of Padova, Department of Economics and Management "Marco Fanno", \\ Via del Santo 33, 35123 Padova
}

Albachiara Boffelli

Università degli Studi di Bergamo, Department of Management, Information and Production Engineering, Via Pasubio, 7, 24044 Dalmine (BG), Italy

Matteo Kalchschmidt

Università degli Studi di Bergamo, Department of Management, Information and Production Engineering, Via Pasubio, 7, 24044 Dalmine (BG), Italy

*corresponding author: ruggero.golini@unibg.it,

TO CITE THIS ARTICLE: Golini, R.; De Marchi, V.; Boffelli, A.; Kalchschmidt, M. (2018). "Which governance structures drive economic, environmental and social upgrading? A quantitative analysis in the assembly industries". International Journal of Production Economics, 203, 13-23. DOI: https://doi.org/10.1016/j.ijpe.2018.05.021

\begin{abstract}
As industries are becoming increasingly global, researchers and practitioners are compelled to look at supply chains (SCs) from a global perspective. In this respect, the Global Value Chain (GVC) framework is particularly useful in understanding global dynamics because it relates the nature of relationships between firms (governance) to the possibilities for firms to move toward higher-value activities (upgrading). Whereas the literature to date has explored these issues via qualitative approaches, this paper explores the effect that different forms of governance with suppliers and customers have on economic (product, process, functional), environmental and social upgrading based on an analysis of the International Manufacturing Strategy Survey (IMSS) data. The results show that participating to GVCs supports only some forms of upgrading and only under specific relational or captive governance structures.
\end{abstract}

Keywords: Supply Chain Management; Global Value Chain; Governance; IMSS; Upgrading 


\section{Introduction}

As a result of globalization, value chains are increasingly fragmented and have spread worldwide. As a consequence, a new era of international competition that is reshaping global production and trade and changing the organization of industries has emerged (Gereffi, 2014; Gereffi and Lee, 2012).

The Global Value Chain (GVC) framework was developed to help understand this new organization of global industries by focusing on the international expansion and geographical fragmentation of supply chains (SCs) and has become increasingly popular in academic publications and analyses of international organizations since the early 2000s (Gereffi and Lee, 2012). Considering all the activities and actors needed to bring a product from conception to end use, the GVC framework allows to understand the ability of firms to create and capture value produced and supports a holistic view of global industries from two contrasting viewpoints: a top-down view, via the concept of governance, and a bottom-up view, via the concept of upgrading (Gereffi, 2014). Governance refers to how global lead firms shape the distribution of profits and the development of industries through different kinds of relationships with their SC partners (Gereffi, 1999a; Gereffi et al., 2005). Upgrading refers to how SC members can capture more of the value created and improve their positions in the global economy by following different trajectories (Gereffi, 1999a; Gereffi and Lee, 2016). Most of the GVC literature revolves around these two concepts, but a clear connection between the forms of governance and the various upgrading possibilities has not yet been established.

Against this background, the purpose of this paper is to measure the impact of different forms of governance on upgrading. The contributions of this paper are twofold. First, the extensive GVC literature investigating the relationship between governance forms and upgrading typologies has been mostly qualitative, focusing on the industry or cluster level and mostly on developed countries (e.g. Giuliani et al., 2005; Humphrey and Schmitz, 2002; Navas-Alemán, 2011). On the contrary, we use a quantitative approach based on a large dataset of firms located in both developed and developing countries and propose a novel methodology to measure governance and upgrading at the firm level by leveraging on well-developed measures derived from the SC 
management literature. Second, we consider the impact of governance structures on different types of upgrading. Where the initial literature focused on economic upgrading (distinguishing among product, process and functional upgrading) (Gereffi, 2005), the relevance of social and environmental upgrading has recently been acknowledged (see Lund-Thomsen and Lindgreen, 2014) yet barely investigated (De Marchi et al., 2013a; Gereffi and Lee, 2016).

The paper is structured as follows. The first section summarizes the previous literature on GVCs and its key concepts of governance and upgrading, highlighting gaps and research opportunities. An explanation of the methodology follows. Then, we present the main empirical results. Finally, the conclusions summarize the contribution provided and outline some future developments.

\section{Literature review and research questions}

The GVC framework highlights the increasing disintegration of activities at the global level and the growing importance of global lead firms in shaping the evolution of industries and their impact on local firms. By analysing the sequence of activities involved in producing goods (or services), a key focus of GVC studies is how value is created and captured within globally expanding value chains. It is important to remind readers that a GVCs differs from a global supply chain (GSC) in that the former provides a higher-level global view of the input-output processes, while the latter usually refers to how the flow of goods and information is managed at the company level with suppliers and customers (Golini et al., 2016). By taking this different perspective, the GVC framework can provide a meaningful and complementary contribution to SC management, particularly through its key concepts of governance and upgrading (Gereffi and Lee, 2012).

\section{The Governance of GVCs}

Both the GVC and SC management literatures have recognized the existence of different kinds of buyer-supplier relationships, ranging from arms' length relationships to collaborative ones. The work of Pilbeam et al. (2012) well summarizes the significant overlap between the meaning of governance as intended by GVC scholars (e.g. Gereffi, 
Humphrey, Nadvi) and other more SC-oriented scholars (e.g. Choi, Harland, Lee). While SC scholars have mainly considered governance from the SC integration point of view (e.g., Golini et al., 2016), in GVC research, governance reflects different ways in which actors exerting particular power along the chain-the so-called global lead firmsmanage the relationships between firms, define the terms of these relationships and shape how, where, when and by whom value is added (Gereffi, 1994; Gereffi et al., 2005). This particular angle to look at governance, which combines power, relationships and geography has been seen as potentially very insightful to enrich existing theories in SC management (Gereffi and Lee, 2012).

More in details, initial contributions about governance in GVCs have emphasized the role of different kinds of lead firms in shaping industries' development trajectories distinguishing between buyer-driven chains (characterized by the powerful role of downstream actors, including global brands and large retailers) and producer-driven chains (where the power is held by final-product manufacturers) (Gereffi, 1994). Later contributions developed this concept by looking at alternative forms in which such powerful actors might coordinate with their first-tier suppliers. Between the two extremes of i) purely price-regulated markets (market governance) and ii) vertical integration (hierarchical governance), Gereffi et al. (2005) identify different types of network governance structures, as follows:

- Modular governance is characterized by codified specification transmitted by buyers to suppliers; collaboration and coordination are necessary, but they are simplified by the information codification so that switching costs are low;

- Relational governance is a network form characterized by frequent interactions and knowledge sharing between buyers and suppliers, supported by reciprocal trust and long-term relationships;

- Captive governance characterizes chains in which suppliers face very high switching costs due to the power of the lead firms (usually very big companies) that control their activities and provide them with the conditions under which they should operate. 
The three network forms of GVC governance are ordered in terms of the degree of explicit coordination and power asymmetry they entail. In particular, relational and captive governance - the latter also called 'quasi-hierarchical' in the work of, for example, Humphrey and Schmitz (2002) and Navas-Alemán (2011) - are characterized by the highest interaction between the lead firms and their suppliers, but in case of captive governance the coordination effort is managed by the lead firm in a more asymmetric manner. While modular VCs have been identified in very few industries (mostly electronics), relational and captive governance structures have been identified in many contexts, being as different as the automotive, apparel and fresh vegetables industries (Gereffi, 1999b; Gereffi, et al., 2005).

In conclusion, one of the key insights of the GVC approach, which increase our knowledge of governance, is the introduction of the concept of power, in addition to the exchange of information that relates to the transaction costs approach. SC literature already analysed the role of power (He et al., 2013; Power, 2005; Robson and Rawnsley, 2001; Singh and Power, 2009), but not its joint effect with transaction costs, which could result in a powerful analytical tool to be tested at large-scale, as it is performed in this paper.

\section{Economic, social and environmental upgrading in GVCs}

The SC management literature has investigated the impact of managerial practices on operational performance, such as cost, lead times, quality (Caniato et al., 2013; Zhao et al., 2013), innovation and, more recently, sustainability (Gualandris et al., 2014). Very rarely have such performance indicators been considered jointly.

Similarly, the GVC research has focused on the concept of (economic) 'upgrading', that is, how different economic stakeholders, firms included, maintain or improve their positions in the global economy and move toward high value-adding activities in GVCs (Gereffi, 2005). Compared to operational performance, upgrading is a broader concept that considers the ability of a firm to increase its share of value added or to improve living standards. The GVC literature provides a classification of distinct 
trajectories through which a company in a specific stage of the VC can pursue economic upgrading (Humphrey and Schmitz, 2002), being as follows:

- Process upgrading refers to the achievement of efficiency improvements in the production process through the reorganization of productive activities;

- Product upgrading refers to the move toward more sophisticated products, entailing higher unit-values;

- Functional upgrading consists of acquiring (or moving toward) new functions with higher skill content (usually marketing, R\&D, branding, distribution);

- Chain or inter-sectoral upgrading, by far the least diffused, refers to moving toward new (often related) industries.

The more GVCs have become pervasive, the greater the concerns about the social and environmental conditions in companies and countries where products are manufactured (Lund-Thomsen and Lindgreen, 2014). In line with the literature on Corporate Social Responsibility (CSR), which supports the importance of a triple bottom line (Elkington, 1997; Carroll, 1999; Gereffi and Lee, 2016), in recent years the GVC literature has increasingly focused on the conditions that allow economic upgrading to be coupled with social and environmental upgrading. A stream of the literature has focused on the conditions that might support the achievement of both economic and social upgrading (Barrientos et al., 2011; Gereffi and Lee, 2016). In this context, social upgrading is intended as the process of improving workers' rights and entitlements and enhancing the quality of their work life (Barrientos et al., 2011). The literature has focused on understanding how workers might benefit from, or are affected by, participating in GVCs, by considering both measurable standards (e.g. wage levels, contract type, health and safety levels) and enabling rights (e.g. freedom of association, voice and empowerment and discrimination). Environmental upgrading - to date the least investigated in the literature-has been defined as the 'process by which economic actors move towards a production system that avoids or reduces the environmental damage from their products, processes or managerial systems' (De Marchi et al., 2013a, p.65). Different approaches through which global lead firms might support the greening of their VCs have been investigated (De Marchi et al., 2013b; Ivarsson and Alvstam, 2010), 
and special attention has been devoted to the (conditions affecting the) effectiveness of codes of conduct in improving labour or environmental conditions (Lund-Thomsen and Lindgreen, 2014).

Two main insights can be gleaned from the extensive literature on upgrading, which is mostly based on empirical evidence on clusters in the context of developing countries. The first insight is that for companies, participating in GVCs represents not only an important market opportunity but also a learning opportunity, to acquire crucial knowledge about global markets, advanced processes and global standards, which is supportive of upgrading (Gereffi, 1999a; Pietrobelli and Rabellotti, 2011). The second insight, an extension of the first, is that the governance structure in place between the lead firms and their suppliers influences to what extent firms can benefit (learn) from GVC participation (Pietrobelli and Rabellotti, 2011) and the development of specific upgrading paths (Humphrey and Schmitz, 2002; Navas-Alemán, 2011). Focusing particularly on captive (and to a lesser degree relational) governance structures - being the most diffused in the contexts analysed, that is, manufacturing industries in developing countries (Humphrey and Schmitz, 2002) - the literature suggests that such governance type is associated with faster product and process upgrading. The underpinning mechanism is that a stronger link between buyers and suppliers, as in the case of captive and relational governance, results in a greater exchange of knowledge to improve products and processes (Navas-Alemán, 2011). However, functional upgrading, which implies changing the scope of a firm's activities, may be locked out, especially in the case of captive governance. In fact, powerful customers usually do not outsource functions that entail higher value-added (such as branding or marketing). This evidence is in line with the Resource-Based View, suggesting that a firm will focus on activities in which it has key and valuable competences and will outsource the others (Wernerfelt, 1984). Regarding social and environmental upgrading, the literature supports the idea that governance matters (e.g. Gereffi and Lee, 2016) but does not focus explicitly on the relationship between different forms of GVC network governance and upgrading outcomes. However, increasing empirical evidence suggests the importance of 'hands-on' governance mechanisms to ensure the effective improvement of workers' 
conditions or of the environmental features of products/processes. More specifically, in terms of social upgrading, the literature supports the superiority of the cooperative paradigm in improving social conditions. As clarified in the literature review by LundThomsen and Lindgreen's (2014), this resembles the relational governance structure because it supports cooperation with local factories and local institutions, and is juxtapose to compliance governance approaches. Similarly, strong interaction with suppliers, both to develop new products and to verify process conditions, has been found to characterize GVCs in which lead firms have effectively managed to reduce environmental harm along the SC (De Marchi et al., 2013b). Indeed, enforcing the application of global standards in relation to workers' conditions requires a long-term relationship, training or the exchange of information between buyer and supplier and frequent on-site visits (Locke et al., 2007). Generalizing this discussion, the research proposition we aim to empirically test is:

Captive and relational governance support economic, social and environmental upgrading better than market governance.

\section{Methodology}

\subsection{Data collection and cleaning}

As suggested in the introductory paragraph, GVC scholars have mainly used the qualitative approach to investigate the relationship between governance and upgrading and to study in-depth the development outcomes of the engagement in GVCs for firms located in specific geographical areas. A key contribution of this paper, being exploratory in nature, is to quantitatively assess this relationship by developing a novel technique to identify the different typologies of governance and upgrading, an effort perceived as urgent in the literature (Gereffi and Lee, 2012).

Bearing in mind that the research can be considered as still in the exploratory stage and that constructs and measures for governance and upgrading have not yet been clearly identified and extensively tested, we decided to adopt secondary data and rely on more consolidated measures, following the approach used in the few quantitative papers on the subject (Pietrobelli and Saliola, 2008). More specifically, to verify our 
assumptions about the relationship between governance and upgrading, we employed data drawn from the sixth edition of the International Manufacturing Strategy Survey (IMSS) ${ }^{1}$, a project carried out by a network of universities that collects data on the manufacturing and SC strategies of firms in the machinery and electronics industries (ISIC codes 25-30). Even though the authors of this paper were directly involved in the data collection, the data can be defined as secondary because they were not collected with the specific purpose of investigating GVCs. This approach has some constraints that will be explained later in the paper. Where required, the questionnaire was translated into the local language (and back-translated to check the quality of the translation) by the partners. Companies were selected based on random or convenience sampling, and each partner took care of the data gathering in their own country, checking also for missing data and non-respondent/late respondent bias. The target respondent was the Operations/Manufacturing Director or an equivalent role.

Even though the survey was not created for the specific research aim of this paper, we believe it might be particularly useful to investigate the issues in question. First, it contains quantitative firm-level information about a large number of firms located in different empirical contexts (i.e. countries, products, positions in the value chain), thus allowing robust analyses. Second, it focuses on homogenous industries (i.e. assembly industries) with comparable approaches to governance and upgrading. Third, it has already been used in the literature to investigate collaboration practices and performance improvements in global SC contexts (Cagliano et al., 2008; Caniato et al., 2013).

From the original sample of 931 cases available in IMSS-VI, we dropped those not providing information relating to the variables investigated in the present study ${ }^{2}$. Table 1 describes the sample in terms of countries, company size and industries.

\footnotetext{
${ }^{1}$ For more information, see www.manufacturingstrategy.net.

${ }^{2}$ We also dropped cases with fewer than 50 employees because they are not compliant with the data collection guidelines. In fact, the IMSS project aims to study the best practices in firms that are large enough to have a structured organization and a defined manufacturing strategy.
} 
Table 1 -Descriptive statistics for the sample

\begin{tabular}{|c|c|c|}
\hline Country & Frequency & Percent \\
\hline China $^{1}$ & 84 & 13.57 \\
\hline Japan & 72 & 11.63 \\
\hline Hungary $^{1}$ & 45 & 7.27 \\
\hline Netherlands & 43 & 6.95 \\
\hline Romania $^{1}$ & 37 & 5.98 \\
\hline Italy & 31 & 5.01 \\
\hline Denmark & 30 & 4.85 \\
\hline Portugal & 27 & 4.36 \\
\hline USA & 27 & 4.36 \\
\hline Brazil $^{1}$ & 26 & 4.2 \\
\hline Finland & 26 & 4.2 \\
\hline Norway & 23 & 3.72 \\
\hline Sweden & 22 & 3.55 \\
\hline Spain & 21 & 3.39 \\
\hline Belgium & 18 & 2.91 \\
\hline Canada & 17 & 2.75 \\
\hline Slovenia & 17 & 2.75 \\
\hline Switzerland & 17 & 2.75 \\
\hline India $^{1}$ & 12 & 1.94 \\
\hline Malaysia $^{1}$ & 11 & 1.78 \\
\hline Taiwan & 9 & 1.45 \\
\hline Germany & 4 & 0.65 \\
\hline Total & 619 & 100 \\
\hline
\end{tabular}

\begin{tabular}{l|l|l|}
\hline $\begin{array}{l}\text { Plant size } \\
\text { (number of } \\
\text { employees) }\end{array}$ & Frequency & Percent \\
\hline Small (50-250) & 277 & 44.75 \\
Medium (250-500) & 97 & 15.67 \\
Large (500+) & 245 & 39.58 \\
\hline Total & $\mathbf{6 1 9}$ & $\mathbf{1 0 0}$ \\
\hline
\end{tabular}

\begin{tabular}{l|l|l|}
\hline ISIC code & Frequency & Percent \\
\hline 25 & 195 & 31.5 \\
26 & 68 & 10.99 \\
27 & 108 & 17.45 \\
28 & 161 & 26.01 \\
29 & 59 & 9.53 \\
30 & 28 & 4.52 \\
\hline Total & $\mathbf{6 1 9}$ & $\mathbf{1 0 0}$ \\
\hline
\end{tabular}

${ }^{1}$ Defined as a developing country

\subsection{Respondents checks and common method bias}

The survey was administered according to the recommendations in the literature (Forza, 2002). The average response rate weighted by the number of cases provided by each country was $36.1 \%$. There was a low rate of missing data for the IMSS-VI, with an average of $6 \%$ per respondent. For the full sample, the average operations experience of the respondents is 12 years, with an average of 13 years spent in the same plant; this constitutes sufficient experience to assess the variables used in the present study, even 
in retrospective terms. Finally, t-tests performed at the country level and focusing on demographic variables such as size, industry and sales revealed no evidence of nonrespondent bias.

Concerning common method bias, anonymity reduced ex ante the likelihood of social desirability, while clarity in item formulation and the brevity of the questions reduced item effects. Ex post, the principal component of data used for this study accounted for only $29 \%$ of the total variance, and a confirmatory factor analysis based on only one factor revealed a very poor fit $(\chi 2 / \mathrm{df}=15.21 ; \mathrm{RMSEA}=0.152 ; \mathrm{CFI}=0.514)$ (Podsakoff et al., 2003). Of note, for 250 randomly selected plants in our sample, we compared survey data about the Returns On Sales in 2012 with secondary information collected by the different partners from economic databases (i.e. Bureau van Dijk). We found a statistically significant correlation between the declared value in IMSS-VI (expressed on a five-point Likert scale) and the actual ROS value $(0.41$; p-value $<0.001)$, thus providing evidence of limited social desirability.

\subsection{Measures}

In this section, we present the measures we developed to capture the impact of GVC participation and of the governance structure on different upgrading possibilities. The complete set of questions used in this study is reported in the Appendix.

To begin, we measured the extent to which plants participate in a GVCs. To this end, the variable GVC_part was measured as the sum of the percentage of purchases and sales outside the country where the plant is based. This measure follows the logic of the backward and forward linkage of a company in a GVCs used by international agencies (OECD, 2012). As participation can be asymmetric (Caniato et al., 2013), we controlled the difference of sales and purchases outside the country (GVC_diff). If GVC_diff is higher than 0 , it means that the company sells to customers internationally more than it buys internationally from suppliers. For instance, a company selling $50 \%$ of its products to international customers and buying $30 \%$ of the components from international suppliers will get a GVC_part value of $80 \%(50 \%+30 \%)$ and a GVC_diff value of $20 \%(50 \%-20 \%)$. 
Next, to investigate our main research proposition, we evaluated the different types of governance using items related to i) the power balance and ii) the nature of the relationship in place (i.e. arms' length vs. collaborative) between actors in the GVCs, in line with the few empirical approaches available in the literature (Humphrey and Schmitz, 2000; Navas-Alemán, 2011). The scant literature using quantitative measures of governance either focuses just on governance with buyers (Pietrobelli and Saliola, 2008) or considers both suppliers and buyers together (e.g. McDermott and Corredoira, 2010). In contrast, we evaluated these two aspects to identify the governance in place both with customers and with suppliers to sustain recent evidence that different nodes of the GVCs might be characterized by different governance structures (Ponte and Sturgeon, 2014). In particular, we assessed power balance using items asking firms to report on the bargaining power of suppliers and customers using a Likert scale of 1-5 (1: very weak5: very high) (He et al., 2013). The nature of the relationship was measured using six different items related to sharing information, collaborative approaches and joint decision making with suppliers and customers. All the measures are 1-5 Likert scales related to the current situation.

Then, we evaluated the different forms of upgrading using items measuring how much firms improved in the different areas over the last three years (again using a 1-5 Likert scales). Regarding economic upgrading 3 , we measured product upgrading through product quality and reliability, product customization and new product introduction (He et al., 2014). To measure process upgrading, we evaluated unit manufacturing cost reduction, ordering cost reduction and manufacturing lead time reduction (Caniato et al., 2013). To measure functional upgrading, we evaluated product assistance and customer service quality 4 . To measure environmental upgrading, we evaluated material, water and energy consumption reduction, and pollution emission and waste reduction

\footnotetext{
${ }^{3}$ Even if the literature suggests the possibility of firms also performing chain upgrading, we excluded it from the analysis of economic upgrading typologies because we could not form expectations about it based on the literature. This is because it has rarely been investigated due to the difficulty of capturing it from an empirical standpoint.

${ }^{4}$ We acknowledge that these items do not capture the entire scope of functional upgrading but only the servitization of manufacturing, as in Clegg et al. (2013). According to the GVC literature, functional upgrading should also include boundary-changing actions (e.g. integrating new functions or moving to a more profitable part of the chain) that are outside the scope of our study because of data constraints.
} 
(Gimenez et al., 2012; Golini et al., 2014). Finally, to measure social upgrading, we evaluated workers' motivation and satisfaction and health and safety conditions (Longoni and Cagliano, 2015; Longoni et al., 2014).

To identify the variables to measure governance and upgrading, we ran an exploratory factor analysis on the variables described above, which revealed that five factors have an eigenvalue higher than 1, even though they explain only $63 \%$ of the variance. Therefore, it is difficult to interpret the results, that is, to associate items to factors, even after rotation. To have a higher explained variance and higher discriminant power among variables, we increased the number of factors to nine (variance explained $=80 \%$, eigenvalues $>0.67$ ). This nine-factors solution is also the one with the lowest Akaike information criterion (AIC) (Schwarz 1978; Akaike, 1987). As the item 'product customization' had significant cross-loadings, it was dropped from the analysis. As a confirmation of the reliability of all the multiple-item factors, the Cronbach's alpha is always greater than 0.7 , except for two constructs. As these are two-item constructs that can lead to lower values of the Cronbach's alpha, we calculated inter-item correlations, which are always significant at the $1 \%$ level. The final solution is reported in Table 2.

Table 2 - Results of the exploratory factor analysis (varimax rotation)

\begin{tabular}{|c|c|c|c|c|c|c|c|c|c|}
\hline Variable & 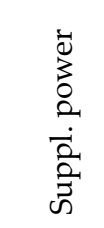 & 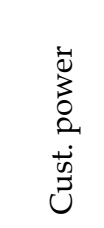 & 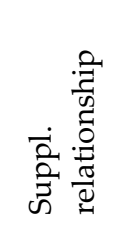 & 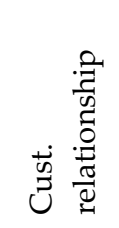 & 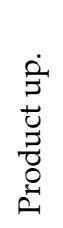 & 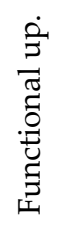 & 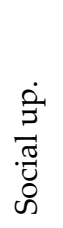 & 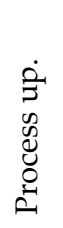 & 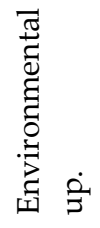 \\
\hline Supplier power & 0.979 & & & & & & & & \\
\hline Customer power & & 0.990 & & & & & & & \\
\hline $\begin{array}{l}\text { Sharing information w/ } \\
\text { suppliers }\end{array}$ & & & 0.810 & & & & & & \\
\hline $\begin{array}{l}\text { Collaboration } \\
\text { w/suppliers }\end{array}$ & & & 0.811 & & & & & & \\
\hline $\begin{array}{l}\text { Joint decision making } \\
\mathrm{w} / \text { suppliers }\end{array}$ & & & 0.755 & & & & & & \\
\hline $\begin{array}{l}\text { Sharing information w/ } \\
\text { customers }\end{array}$ & & & & 0.844 & & & & & \\
\hline $\begin{array}{l}\text { Collaboration w/ } \\
\text { customers }\end{array}$ & & & & 0.853 & & & & & \\
\hline $\begin{array}{l}\text { Joint decision making } \\
\text { w/ customers }\end{array}$ & & & & 0.807 & & & & & \\
\hline
\end{tabular}




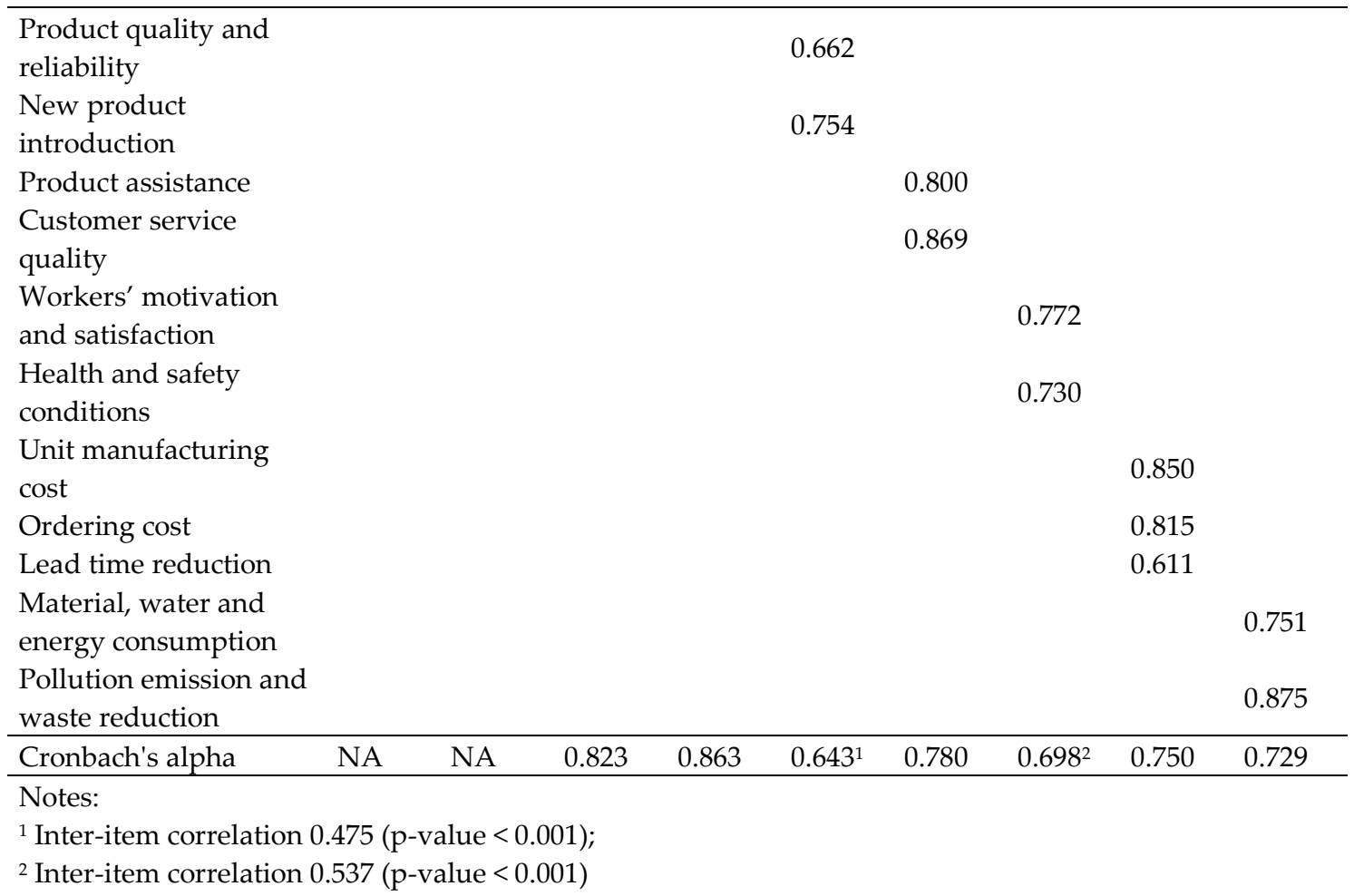

All the multiple-item factors were calculated by averaging the values of the related items. Interestingly, bargaining power with suppliers and customers load separately on two different factors and were treated as single-item variables.

Based on the literature, we defined the different governance structures as follows:

- Captive governance with suppliers (or customers) is equal to 1 when the relationship with suppliers (or customers) is highly collaborative (i.e. $>=4$ out of 5) and the bargaining power of suppliers (or customers) is very strong (i.e. $>=4$ out of 5). In other words, the company is 'captivated' by suppliers (or customers) and needs to exchange information with them.

- Relational governance with suppliers (or customers) is equal to 1 when the type of relationship with suppliers (or customers) is also highly collaborative (i.e. $>=4$ out of 5 ) but the bargaining power of suppliers (or customers) is medium or weak (i.e. $<4$ out of 5$)$. 
In all other cases, the governance is presumed to be market governance ${ }^{5}$.

In Table 3, we report the distribution of the governance forms identified using this approach. Almost half of the companies in our sample engage in VCs characterized by governance structures different from market, either with customers or with suppliers. Captive governance is more likely when it comes to suppliers, and relational governance is more likely when it comes to customers. Another interesting result emerging from Table 3 is that different nodes of the chain are characterized by different governance structures, confirming the framework proposed by Ponte and Sturgeon (2014). Indeed, more than one third of the companies in our sample experience a different type of governance downstream (with their buyers) and upstream (with their suppliers).

Table 3 - Governance typologies with suppliers and customers

\begin{tabular}{ll|cccc}
\hline & & \multicolumn{4}{c}{ Governance w/ customer } \\
& & Market & Relational & Captive & Total \\
\hline \multirow{3}{*}{ Governance } & Market & 325 & 47 & 28 & 400 \\
w/ suppliers & Relational & 27 & 40 & 11 & 78 \\
& Captive & 45 & 55 & 41 & 141 \\
& Total & 397 & 142 & 80 & 619 \\
\hline
\end{tabular}

Finally, we take into account several potential alternative explanations-plant size, location in a developed or developing country and membership in a company-wide international manufacturing network and market dynamicity. Company size (SizeLn) is measured as the logarithm of the number of employees and is included because it is a relevant contingent variable when considering the value chain configuration and improvement programs (Caniato et al., 2013). The location in a developing country (Developing) was assessed using the International Monetary Fund classification

\footnotetext{
5 The typology introduced by Gereffi et al. (2005) also includes modular governance. However, such a governance structure has been found to be uncommon in sectors other than electronics, which is partially out of the empirical scope of this paper. Therefore, we are confident that the residual of relational and captive forms, as calculated in this paper, is going to be just market structures and not modular ones. Still, to partially control for this potential source of variance, we introduced in the analysis product-design modularity, a dummy variable based on a 1-5 Likert scale question asking whether the product has a modular or integrated product design. Such a measure is consistent with the literature, where it is reported that modular governance is related to modular product design (Gereffi et al., 2005).
} 
(considering developing and newly industrialized countries). In particular, India, Brazil, China, Hungary, Romania and Malaysia were classified as developing. Membership in a company-wide international manufacturing network (IMN) was assessed using a specific question asking whether the company had affiliate plants outside the country (420 plants are part of a firm-wide international network). Finally, market dynamicity was measured as the average of two items related to market size (1: declining rapidly -5 : growing rapidly) and the rate of technological change (1: very low-5: very high) (correlation 0.335 , sig. $<0.001$ ). We did not introduce an industry variable because it proved not to be significant, in line with other studies using the same dataset (Caniato et al., 2013). Descriptive statistics for the variables used in the analysis are reported in Table 4.

Table 4-Descriptive statistics for the variables used in the analysis

\begin{tabular}{|c|c|c|c|c|c|c|}
\hline & Variable & Obs & Mean & Std. Dev. & Min & Max \\
\hline \multirow{5}{*}{$\begin{array}{l}\dot{\vec{v}} \\
\frac{\partial}{\Delta} \\
\dot{\Delta}\end{array}$} & Prod-Upgr & 619 & 3.2 & 0.8 & 1.0 & 5.0 \\
\hline & Proc-Upgr & 619 & 2.6 & 0.8 & 1.0 & 5.0 \\
\hline & Funct-Upgr & 619 & 2.9 & 0.8 & 1.0 & 5.0 \\
\hline & Env-Upgr & 619 & 2.7 & 0.8 & 1.0 & 5.0 \\
\hline & Soc-Upgr & 619 & 3.0 & 0.8 & 1.0 & 5.0 \\
\hline \multirow{4}{*}{ 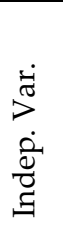 } & RelCust & 619 & 0.23 & - & 0.0 & 1.0 \\
\hline & RelSup & 619 & 0.13 & - & 0.0 & 1.0 \\
\hline & CaptCust & 619 & 0.13 & - & 0.0 & 1.0 \\
\hline & CaptSup & 619 & 0.23 & - & 0.0 & 1.0 \\
\hline \multirow{5}{*}{$\begin{array}{l}\frac{\infty}{0} \\
\stackrel{0}{0} \\
0 \\
0\end{array}$} & SizeLn & 619 & 6.0 & 1.7 & 3.9 & 11.8 \\
\hline & GVC_Part & 619 & 92.5 & 60.0 & 0.0 & 200.0 \\
\hline & GVC_Diff & 619 & 10.5 & 34.1 & -100.0 & 100.0 \\
\hline & Market-dyn & 619 & 3.2 & 0.7 & 1.0 & 5.0 \\
\hline & Modularity & 619 & 0.78 & - & 0.0 & 1.0 \\
\hline
\end{tabular}

\section{Results and discussion}

To assess the impact of governance on the different typologies of upgrading, we ran a linear regression (Table 5). To ensure the robustness of the results, we checked that multicollinearity does not affect the quality of the results. Variance inflation factors were 
all below 1.3; the literature recommends cut-off values of around 5 (Hair et al., 1998; Menard, 2002). Moreover, we checked that interaction effects between governance, belonging to a developing country and participation in the GVCs have a very limited effect.

Table 5 - Testing the relationships between governance and upgrading (standardized betas are reported)

\begin{tabular}{lcccccccccc}
\hline & \multicolumn{2}{c}{ Prod-Upgr } & \multicolumn{2}{c}{ Proc-Upgr } & \multicolumn{2}{c}{ Funct-Upgr } & \multicolumn{2}{c}{ Soc-Upgr } & \multicolumn{2}{c}{ Env-Upgr } \\
& beta & $\mathrm{p}$ & beta & $\mathrm{p}$ & beta & $\mathrm{p}$ & beta & $\mathrm{p}$ & beta & $\mathrm{p}$ \\
\hline GVC_Part & $.113^{* * *}$ & 0.005 & $.176^{* * *}$ & 0.000 & 0.039 & 0.338 & 0.062 & 0.142 & $.089^{* *}$ & 0.039 \\
GVC_Diff & 0.016 & 0.677 & 0.009 & 0.825 & 0.008 & 0.83 & -0.008 & 0.833 & -0.03 & 0.461 \\
RelCust & $.091^{* *}$ & 0.026 & $.115^{* * *}$ & 0.007 & $.109^{* * *}$ & 0.008 & $.105^{* *}$ & 0.012 & $.095^{* *}$ & 0.028 \\
CaptCust & $.149^{* * *}$ & 0 & 0.017 & 0.696 & $.146^{* * *}$ & 0.001 & $.098^{* *}$ & 0.026 & 0.072 & 0.114 \\
RelSup & 0.037 & 0.380 & 0.064 & 0.155 & $.085^{* *}$ & 0.047 & $.087^{* *}$ & 0.047 & 0.063 & 0.163 \\
CaptSup & 0.050 & 0.217 & $.091^{* *}$ & 0.034 & $.098^{* *}$ & 0.017 & $.105^{* *}$ & 0.013 & $.100^{* *}$ & 0.021 \\
\hline Modularity & 0.025 & 0.509 & -0.017 & 0.66 & 0.022 & 0.564 & 0.053 & 0.168 & 0.012 & 0.756 \\
SizeLn & -0.042 & 0.301 & -0.022 & 0.602 & $-.098^{* *}$ & 0.015 & -0.017 & 0.674 & 0.03 & 0.488 \\
Market-dyn & $.263^{* * *}$ & 0.000 & $.126^{* * *}$ & 0.002 & $.192^{* * *}$ & 0.000 & $.181^{* * *}$ & 0.000 & $.098^{* *}$ & 0.019 \\
IMN & -0.035 & 0.398 & -0.047 & 0.283 & -0.027 & 0.517 & -0.012 & 0.776 & -0.015 & 0.739 \\
Developing & $.150^{* * *}$ & 0.000 & -0.056 & 0.178 & $.161^{* * *}$ & 0.000 & $.089^{* *}$ & 0.028 & 0.03 & 0.481 \\
\hline R-squared & 0.176 & & 0.082 & & 0.162 & & 0.121 & & 0.064 & 619 \\
Observations & 619 & & 619 & & 619 & & 619 & & 619 & \\
\hline
\end{tabular}

** significant at $5 \%$ level. ${ }^{* * *}$ significant at $1 \%$ level. Results significant at the $10 \%$ level not considered.

\subsection{GVC Participation}

Interestingly, participation in GVCs has a significant relationship with all forms of upgrading, except functional and social. While functional upgrading is considered the most relevant form of economic upgrading, given the highest value-adding potential it entails, this evidence provides food for thought for scholars interested in understanding the impact of firms' participation in GVCs. Indeed, it challenges the idea that participating in global markets can support higher economic and social results. To better explain this result, we interacted the variable GVC_Part with Developing to verify if the characteristics of the country in which the company is located might drive this results, as reported in Table 6. 
Table 6 - Results of the interaction between participation in GVCs and the location in developing countries (other variables omitted)

\begin{tabular}{lcccccccccc}
\hline & \multicolumn{2}{c}{ Prod-Upgr } & \multicolumn{2}{c}{ Proc-Upgr } & \multicolumn{2}{c}{ Funct-Upgr } & \multicolumn{2}{c}{ Soc-Upgr } & \multicolumn{2}{c}{ Env-Upgr } \\
& beta & $\mathrm{p}$ & beta & $\mathrm{p}$ & beta & $\mathrm{p}$ & beta & $\mathrm{p}$ & beta & $\mathrm{p}$ \\
\hline GVC_Part & $.183^{* * *}$ & .000 & $.185^{* * *}$ & .000 & $.101^{* *}$ & .029 & $.158^{* * *}$ & .002 & .101 & .058 \\
GVC_Part*Developing & $-.145^{* *}$ & .017 & -.021 & .760 & $-.157^{* *}$ & .017 & $-.215^{* * *}$ & -.001 & -.027 & .700 \\
\hline
\end{tabular}

** significant at the 5\% level. *** significant at the $1 \%$ level. Results significant at the $10 \%$ level not considered.

The results suggest that participation in GVCs might even be detrimental to upgrading in the context of developing countries, at least in the case of functional and social upgrading. Another interesting result of our analysis is that it is not the direction (upstream vs. downstream) but the extent of the participation in global markets that affects upgrading possibilities. Indeed, the variable GVC_Diff is never significant. While SC management literature is often focused on the impacts of global sourcing (i.e., supplying materials and components from foreign suppliers), our results indicate that considering jointly international purchasing and sales is necessary to understand the capacity of the firm to improve its competitive position in global SCs, as introduced by Caniato et al. (2013).

\subsection{Governance forms with suppliers and customers}

Regarding the different forms of governance, product upgrading is mostly driven by the connection with customers; both relational and captive governance structures are more viable than the market governance structures in supporting the development of new products or the improvement of existing ones, which is in line with the literature (e.g. Navas-Alemán, 2011). This does not mean that tight relationships with suppliers are useless in improving products, but that, in the empirical context analyzed, they might depend on specific situations. This evidence should stimulate SC scholars to further research "triads" of companies (buyer, tier-1 and tier-2 suppliers) and their relationships, especially when engaged in radical new product development. 
Evidence regarding process upgrading is less straightforward; indeed, our results suggest that it is supported by relational governance with customers and by captive governance with suppliers. In relational governance with customers, thanks to information exchange, suppliers can organize themselves in terms of production schedules and inventory management to better serve the customers. Moreover, the knowledge and help to improve processes may come directly from customers, for instance, in the form of supplier development programs (Watts and Hahn, 1993; Handfield, et al., 2000). On the other side, a high power over suppliers allows the buyer company to align the suppliers' operations with its own needs, further increasing the speed and cost effectiveness of processes. The drawback of this practice is that when costs are pushed back to the suppliers, the latters have less opportunities to improve their own processes - which might explain why a captive form of governance with customers is not related to process upgrading.

All the forms of network governance considered (relational and captive, with suppliers and customers) are more helpful than market governance in implementing functional upgrading. The possibility of moving toward higher value-added activities, such as providing service to customers, can take place just in contexts characterized by 'hands-on' mechanisms, supporting the evidence reported in Navas-Alemán (2011). However, the fact that captive governance might be as relevant as relational governance in spurring functional upgrading is novel with respect to the expectations drawn by the literature. Further analyses should verify if such results might be driven by the specific empirical context analysed (e.g. the focus on the assembly industry) or the fact that we considered just the servitization of industry as functional upgrading (see footnote 3).

Social upgrading follows the same pattern, even though the significance of the relationship with the customer is slightly lower. The development and enforcement of standards to ensure the quality of work life requires intense interactions between SC partners, which could not take place in the case of market governance. Finally, environmental upgrading is supported by relational governance with customers and by captive governance with suppliers, following a path similar to that characterizing process upgrading. Indeed, the reduction of environmental harm caused by production 
activities is often achieved, at least as a first step, by improving companies' production processes (Walton, et al., 1998; Vachon and Klassen, 2006).

\subsection{Interaction effects and control variables}

Considering that the literature focused predominantly on developing countries, we also verified whether the results could be affected by the company location by adding to the analysis the interaction variables between the four governance structures considered and the variable Developing. The interaction effects are generally not significant in any of the upgrading typologies considered, indicating that our results are valid for companies in both developed and developing countries. The only significant result $(\mathrm{p}<0.05)$ was found for captive governance with customers, which has a detrimental effect on social upgrading in firms in developing countries. This is quite an alarming result, as it looks like, despite the close connection with their customers, in a developed country it is likely that suppliers have no incentive to improve their social sustainability performance. This is in line with the literature supporting the limitations of the compliance-based approach (Lund-Thomsen and Lindgreen, 2014).

Finally, regarding the control variables, market dynamicity (Market-dyn) is particularly useful in explaining how much firms are improving in terms of all five upgrading typologies considered. This is not surprising, as it reflects the need to be innovative in high clockspeed markets (Fine, 2000). In addition, the location in a developing country (Developing) is supportive of a higher level of upgrading, even though, as discussed above, this result might not be driven by GVC participation but seems likely to relate to a 'catching up' process in which developing countries' firms are attempting to perform in the same way as firms in developed countries. Size (SizeLn) is never significant in explaining upgrading possibilities, except for functional upgrading, supporting the idea that smaller firms might be better able to seize the opportunities related to the move toward activities entailing higher value-added. Membership in an international manufacturing network (INM) is never significant. 


\subsection{The empirical framework}

Ultimately, the analysis of the results allowed us to develop some ex-post propositions useful to critically discuss the insights gained with a holistic view and to give directions for future research.

Following are the ex-post propositions:

- P1: Participation in GVCs positively affects product, process and environmental upgrading.

- P2a: Captive governance with customers supports product, functional and social upgrading to a greater extent than market governance.

- P2b: Relational governance with customers supports all forms of upgrading to a greater extent than market governance.

- P2c: Captive governance with suppliers supports process, functional, social and environmental upgrading to a greater extent than market governance.

- P2d: Relational governance with suppliers supports functional and social upgrading to a greater extent than market governance.

Figure 1 graphically depicts the results of this paper and the propositions we derived.

Figure 1 - The relationship between governance with customers and suppliers and economic, social, and environmental upgrading: the empirical framework

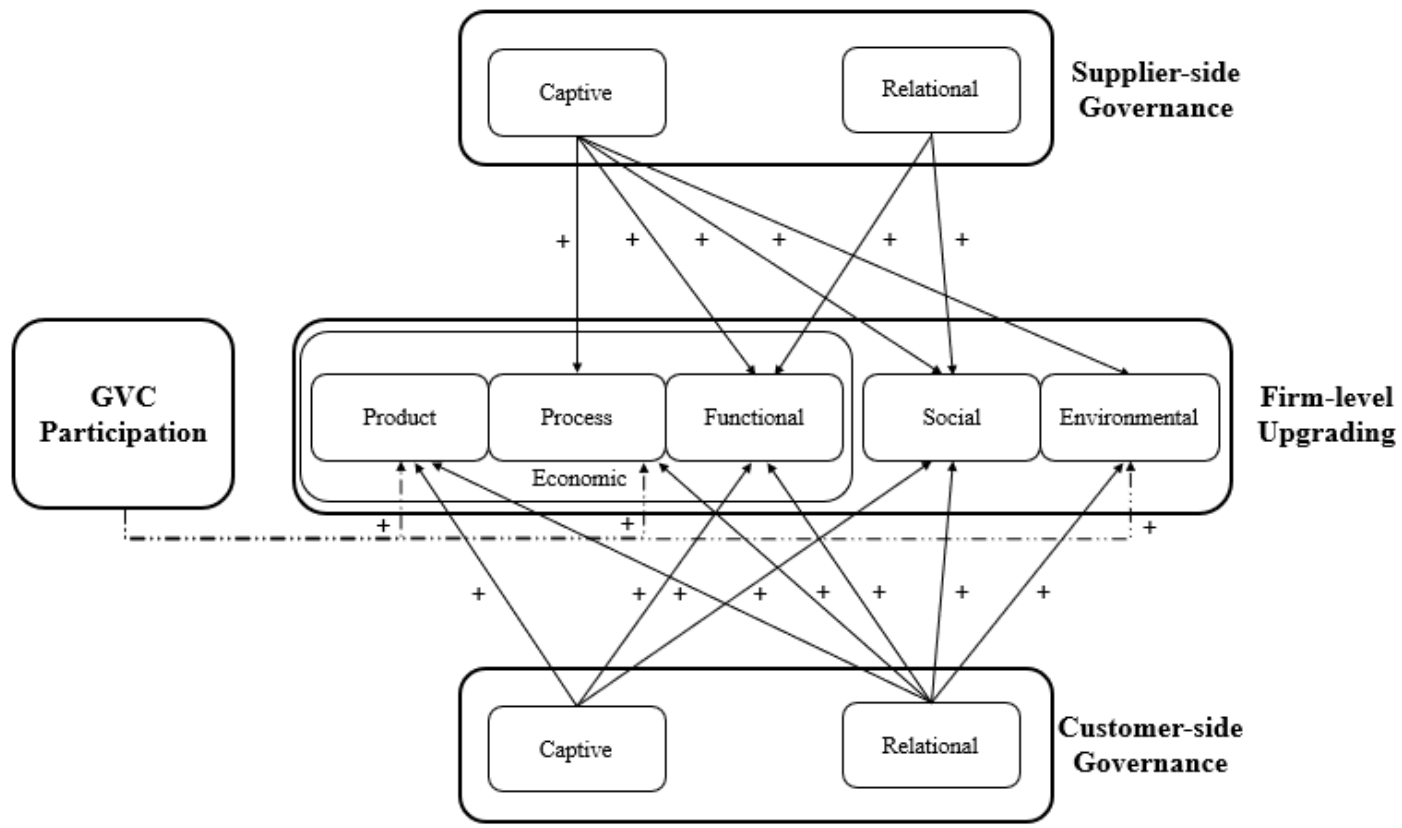


In sum, we can observe that relational governance is more effective on the customer side than on the supplier side in triggering upgrading. In fact, this kind of collaborative governance supports all forms of upgrading on the customer side but only two forms on the supplier side. However, regarding the forms of upgrading where supplier-side collaborative governance falls short (i.e. product and environmental upgrading), firms can find support in the form of GVC participation.

\section{Conclusions}

The results presented in this paper help to refine and deepen the broad assumptions about the linkages between governance and upgrading, being a central topic in the GVC literature and with significant implications for SC management too. In particular, we focus on the governance forms characterized by the high exchange of information between partners--namely, relational and captive governance-with power held by the external partner being the main discriminant between the two. An important contribution of our analysis is that we have not limited the scope of our study to a single side of the SC, acknowledging that different nodes of the GVCs might be characterized by different governance structures (Ponte and Sturgeon, 2014). Furthermore, where the majority of the literature has focused on one type of upgrading at a time, we considered economic (distinguishing across product, process and functional), social and environmental upgrading, addressing a need that remained rather neglected (Bolwig et al., 2010).

Overall, our findings support that relational and captive governance are supportive of upgrading especially when customers are involved, thus supporting the role of (large) buyers in shaping industries, which is a core element of GVC empirical analyses (Gereffi, 1994). However, our fine grain analysis of different typologies of governance and upgrading highlights several interesting differences. With reference to Figure 1, relational governance on the customer side is supportive of all types of upgrading considered, whereas, on the supplier side, it only supports functional and social upgrading. Additionally, captive governance on the supplier side is supportive of all upgrading types considered except for product upgrading, whereas on the customer 
side it supports all upgrading types except for process and environmental ones. Interestingly, GVC participation is not supportive of functional and social upgrading, suggesting that the magnitude of engagement in global markets (both upstream or downstream) might not be relevant for such complex forms of improvements. This is in line with recent empirical contributions arguing that local SCs might be supportive of higher sustainability performance (Chiarvesio et al., 2015; De Marchi et al., 2013b).

In conclusion, the paper contributes to the GVC literature and to SC management research, on the one hand providing new insights on the effects of governance on upgrading, on the other hand explaining how the level of participation in global SCs might or might not become a lever for improving the firm competitiveness. More specifically, for SC management scholars we suggest the relevance of governance which measures simultaneously the extent of collaboration and the role of power in relation - in understanding the possibilities for a firm to improve its operational performance, including sustainability ones. Furthermore, our study provides insights for GVC scholars, as it is testing in a specific empirical setting new ways to quantitatively measure governance and upgrading using firm-level data, responding to an urgent call by Gereffi and Lee (2012). The empirical methodology we are proposing is based on solid indicators, as they are widely adopted in the SC management literature, which could also be easily and effectively replicated in other empirical contexts; and allows for analysing the role of supplier-side collaborations too.

The paper also generates some practical contributions by giving managers advice about how to leverage collaboration with customers and suppliers to achieve different forms of upgrading. Indeed, the results suggest that, for companies, the viability of trajectories of improvements might change even within the same industry, depending on the relationships in place between actors, the power exerted by them and the geography of the SC (engaging with customers or suppliers based in developing or developed countries). Finally, our study provides food for thought for policy makers interested in evaluating the impact of the engagement of local firms in the global economy in terms of economic, social and environmental upgrading. At least in the context of global assembly industries, the study suggests that participation in GVCs is 
not necessarily enabling local firms to move toward more profiting activities (functional upgrading) or to improve local working conditions (social upgrading), especially if we are considering the developing countries context, and that the form of collaboration among local firms and with global ones is important in understanding such performance possibilities. The possibility for local industries to upgrade need to be planned and understood by managers and policy makers using firm-level analyses.

While the adoption of a quantitative empirical approach is a key contribution of this paper, it also causes some of its key limitations, especially considering that we are using secondary data. A key open question that future research should address is the extent to which different forms of governance are leading to jointly achieve economic, social and environmental upgrading or at least to determine which combinations of the three forms of upgrading are driven by which conditions in terms of governance and the degree of participation to GVCs. This is a particularly relevant issue for the literature adopting GVC frameworks to understand CSR dynamics (Lund-Thomsen and Lindgreen, 2014). Accordingly, an open research question is to determine to what extent the achievement of one form of upgrading leads to another (i.e. if achieving functional upgrading is also supportive of environmental upgrading). Finding an answer to this question will also provide new insights to enrich the debate about trade-offs and cumulative capabilities (Ferdows and De Meyer, 1990). In fact, after Skinner (1996) defined the generic operations capabilities as concerning cost efficiency, quality, dependability and flexibility, some authors questioned the assumption of their being in a continuous trade-off, depending on the organization objectives. Ferdows and De Meyer's (1990) cumulative capabilities theory, suggesting that capabilities can build on each other by being developed in a specific sequence, became very popular in the field of operations management. Even if, in recent years, scholars have started to wonder whether different models could apply in different environments (Flynn and Flynn, 2004; Singh et al., 2015), the assumption of cumulative capabilities is commonly accepted, meaning that capabilities are not necessarily in a trade-off. More recently, other capabilities (e.g. social and environmental sustainability) have been added to the initial set, and an intriguing issue is how they integrate in the previous operations strategy 
(Longoni and Cagliano, 2015). Similarly, the different upgrading forms could build on each other, and finding the right sequence will constitute a key contribution to cumulative capability theory and will help practitioners to understand how to build long-lasting capabilities (Ferdows and De Meyer, 1990). Another interesting development would be to determine if different forms of social and environmental upgrading can be identified, similar to what has been done for economic upgrading, in line with De Marchi et al. (2013a) and Barrientos et al. (2011).

Additionally, further research should verify to what extent the emerging evidence might be driven by the specific set of industries considered in the analyses or the way in which measures have been developed. Consequently, a survey should be specifically designed to assess the research propositions put forth here. Moreover, it could be applied in different contexts to cross-validate the results. Alternatively, as a subset of companies participated in several editions of the survey, future research could adopt a longitudinal approach to validate the results.

\section{References}

Akaike, H. (1987). Factor analysis and AIC. Psychometrika, 52(3), 317-332. doi: https://doi.org/10.1007/BF02294359

Barrientos, S., Gereffi, G., and Rossi, A. (2011). Economic and social upgrading in global production networks: A new paradigm for a changing world. International Labour Review, 150(3-4), 319-340. doi: https://doi.org/10.1111/j.1564-913X.2011.00119.x

Bolwig, S., Ponte, S., Du Toit, A., Riisgaard, L., and Halberg, N. (2010). Integrating poverty and environmental concerns into value-chain analysis: a conceptual framework. Development Policy Review, 28(2), 173-194. doi: https://doi.org/ 10.1111/j.1467-7679.2010.00480.x

Cagliano, R., Caniato, F., Golini, R., Kalchschmidt, M., and Spina, G. (2008). Supply chain configurations in a global environment: A longitudinal perspective. Operations Management Research, 1(2), 86-94. doi: https://doi.org/10.1007/s12063-008-00120 
Caniato, F., Golini, R., and Kalchschmidt, M. (2013). The effect of global supply chain configuration on the relationship between supply chain improvement programs and performance. International Journal of Production Economics, 143(2), 285-293. doi: https://doi.org/10.1016/j.ijpe.2012.05.019

Carroll, A. B. (1999). Corporate social responsibility: Evolution of a definitional $\begin{array}{llll}\text { construct. Business } & \mathcal{E} & \text { society, 38(3), 268-295. doi: }\end{array}$ https://doi.org/10.1177/000765039903800303

Chiarvesio, M., Marchi, V. D., and Maria, E. D. (2015). Environmental innovations and internationalization: Theory and practices. Business Strategy and the Environment, 24(8), 790-801. doi: https://doi.org/10.1002/bse.1846

Clegg, J. M., Prasanta Dey, B., Lightfoot, H., Baines, T., and Smart, P. (2013). The servitization of manufacturing: A systematic literature review of interdependent trends. International Journal of Operations and Production Management, 33(11/12), 1408-1434.

De Marchi, V., Di Maria, E., and Micelli, S. (2013a). Environmental Strategies, Upgrading and Competitive Advantage in Global Value Chains. Business Strategy and the Environment, 22, 62-72. doi: https://doi.org/10.1002/bse.1738

De Marchi, V., Di Maria, E., and Ponte, S. (2013b). The greening of global value chains: Insights from the furniture industry. Competition and Change, 17(4), 299-318. doi: https://doi.org/10.1179/1024529413Z.00000000040

Demeter, K., and Golini, R. (2014). Inventory configurations and drivers: An international study of assembling industries. International Journal of Production Economics, 157, 62-73. doi: https://doi.org/10.1016/j.ijpe.2013.10.018

Elkington, J. (1997). Cannibals with Forks: The Triple Bottom Line of 21st Century Business. Stony Creek: New Society Publishers.

Ferdows, K., and De Meyer, A. (1990). Lasting improvements in manufacturing performance: in search of a new theory. Journal of Operations management, 9(2), 168-184. doi: https://doi.org/10.1016/0272-6963(90)90094-T 
Fine, C. H. (2000). Clockspeed-based strategies for supply chain design. Production and Operations Management, 9(3), 213-221. doi: https://doi.org/10.1111/j.19375956.2000.tb00134.x

Flynn, B. B., and Flynn, E. J. (2004). An exploratory study of the nature of cumulative capabilities. Journal of operations management,22(5), 439-457. doi: https://doi.org/10.1016/j.jom.2004.03.002

Forza, C. (2002). Survey research in operations management: a process-based perspective. International Journal of Operations and Production Management, 22(2), 152-194. doi: https://doi.org/10.1108/01443570210414310

Gereffi, G. (1994). The organization of buyer-driven global commodity chains: How US retailers shape overseas production networks. In G. Gereffi, and M. Korzeniewicz, Commodity Chains and Global Capitalism (p. 95-122). Westport, CT: Praeger.

Gereffi, G. (1999a). A commodity chains framework for analyzing global industries. Institute of Development Studies, 8(12), 1-9.

Gereffi, G. (1999b). International trade and industrial upgrading in the apparel commodity chain. Journal of International Economics, 48(1), 37-70. doi: https://doi.org/10.1016/S0022-1996(98)00075-0

Gereffi, G. (2005). The global economy: organization, governance and development. In N. J. Smelser, and R. Swedberg, The Handbook of Economic Sociology (p. 160-182). Princeton: Princeton University Press.

Gereffi, G. (2014). Global value chains in a post-Washington Consensus world. Review of International Political Economy, 21(1), 9-37. doi: https://dx.doi.org/10.1080/09692290.2012.756414

Gereffi, G., and Lee, J. (2012). Why the world suddenly cares about global supply chains. Journal of Supply Chain Management, 48(3), 24-32. doi: https://doi.org/10.1111/j.1745-493X.2012.03271.x

Gereffi, G., and Lee, J. (2016). Economic and social upgrading in global value chains and industrial clusters: Why governance matters. Journal of Business Ethics, 133(1), 2538. doi:https://doi.org/10.1007/s10551-014-2373-7 
Gereffi, G., Humphrey, J., and Sturgeon, T. (2005). The governance of global value chains. Review of International Political Economy, 12, 78-104. doi: http://dx.doi.org/10.1080/09692290500049805

Gimenez, C., Sierra, V., and Rodon, J. (2012). Sustainable operations: Their impact on the triple bottom line. International Journal of Production Economics, 140(1), 149-159. doi: https://doi.org/10.1016/j.ijpe.2012.01.035

Giuliani, E., Pietrobelli, C., and Rabellotti, R. (2005). Upgrading in global value chains: lessons from Latin American clusters. World Development, 33(4), 549-573. doi: https://doi.org/10.1016/j.worlddev.2005.01.002

Golini, R., Caniato, F., and Kalchschmidt, M. (2016). Linking Global Value Chains and Supply Chain Management: Evidence from the Electric Motors Industry. Production Planning and Control, 27(11), 934-951. doi: http://dx.doi.org/10.1080/09537287.2016.1170225

Golini, R., Longoni, A., and Cagliano, R. (2014). Developing sustainability in global manufacturing networks: the role of site competence on sustainability performance. International Journal of Production Economics, 147(Part B), 448-459. doi: https://doi.org/10.1016/j.ijpe.2013.06.010

Gualandris, J., Golini, R., and Kalchschmidt, M. (2014). Do supply management and global sourcing matter for firm sustainability performance? An international study. Supply Chain Management: An International Journal, 19 (3), 258-274. doi: https://doi.org/10.1108/SCM-11-2013-0430

Hair, J.F., Black, W.C., Babin, B.J., Anderson, R.E., and Tatham, R.L. (1998). Multivariate data analysis. Prentice hall Upper Saddle River, NJ.

Handfield, R., Krause, D., Scannell, T., and Monczka, R. M. (2000). Avoid the pitfalls in Supplier Development. Sloan Management Review, 41(2), 37-49.

He, Q., Ghobadian, A., and Gallear, D. (2013). Knowledge acquisition in supply chain partnerships: The role of power. International Journal of Production Economics, 141(2), 605-618. doi: https://doi.org/10.1016/j.ijpe.2012.09.019

He, Y., Lai, K. K., Sun, H., and Chen, Y. (2014). The impact of supplier integration on customer integration and new product performance: the mediating role of 
manufacturing flexibility under trust theory. International Journal of Production Economics, 147, 260-270. doi: https://doi.org/10.1016/j.ijpe.2013.04.044

Humphrey, J., and Schmitz, H. (2000). Governance and upgrading: linking industrial cluster and global value chain research. Institute of Development Studies Brighton.

Humphrey, J., and Schmitz, H. (2002). How does insertion in global value chains affect upgrading in industrial clusters? Regional Studies, 36(9), 1017-1027. doi: http://dx.doi.org/10.1080/0034340022000022198

Ivarsson, I., and Alvstam, C. G. (2010). Supplier Upgrading in the Home-furnishing Value Chain: An Empirical Study of IKEA's Sourcing in China and South East Asia. World Development, 38(11), 1575-1587. doi: https://doi.org/10.1016/j.worlddev.2010.04.007

Lee, J. (2010). Global commodity chains and global value chains. In The International Studies Encyclopedia (p. 2987-3006). Oxford: Wiley-Blackwell.

Locke, R. M., Qin, F., and Brause, A. (2007). Does Monitoring Improve Labor Standards? Lessons from Nike. ILR Review, 61(1), 3-31. doi: https://doi.org/10.1177/001979390706100101

Longoni, A., and Cagliano, R. (2015). Environmental and social sustainability priorities: Their integration in operations strategies. International Journal of Operations and Production Management, 35(2), 216-245. doi: https://doi.org/10.1108/IJOPM-042013-0182

Longoni, A., Golini, R., and Cagliano, R. (2014). The role of New Forms of Work Organization in developing sustainability strategies in operations. International Journal of Production Economics, 147(Part A), 147-160. doi: https://doi.org/10.1016/j.ijpe.2013.09.009

Lund-Thomsen, P., and Lindgreen, A. (2014). Corporate social responsibility in global value chains: Where are we now and where are we going? Journal of Business Ethics, 123(1), 11-22. doi: https://doi.org/10.1007/s10551-013-1796-x

McDermott, G. A., and Corredoira, R. A. (2010). Network composition, collaborative ties, and upgrading in emerging-market firms: Lessons from the Argentine autoparts sector. Journal of International Business Studies, 41(2), 308-329. doi: https://doi.org/10.1057/jibs.2009.7 
Menard, S.W., 2002. Applied logistic regression analysis. Sage Publications, Inc, Thousand Oaks, USA.

Navas-Alemán, L. (2011). The Impact of Operating in Multiple Value Chains for Upgrading: The Case of the Brazilian Furniture and Footwear Industries. World Development, $\quad 39(8), \quad$ 1386-1397. doi: https://doi.org/10.1016/j.worlddev.2010.12.016

OECD (2012). Mapping global value chains. Report of the OECD. available at: https://www.oecd.org/dac/aft/MappingGlobalValueChains_web_usb.pdf

Pietrobelli, C., and Rabellotti, R. (2011). Global Value Chains Meet Innovation Systems: Are There Learning Opportunities for Developing Countries? World Development, 39(7), 1261-1269. doi: https://doi.org/10.1016/j.worlddev.2010.05.013

Pietrobelli, C., and Saliola, F. (2008). Power relationships along the value chain: multinational firms, global buyers and performance of local suppliers. Cambridge Journal of Economics, 32(6), 947-962. doi: https://doi.org/10.1093/cje/ben016

Pilbeam, C., Alvarez, G., and Wilson, H. (2012). The governance of supply networks: a systematic literature review. Supply Chain Management: An International Journal, 17(4), 358-376. doi: https://doi.org/10.1108/13598541211246512

Podsakoff, P. M., MacKenzie, S. B., Lee, J. Y., and Podsakoff, N. P. (2003). Common method biases in behavioral research: a critical review of the literature and recommended remedies. Journal of applied psychology,88(5), 879. doi: http://dx.doi.org/10.1037/0021-9010.88.5.879

Ponte, S., and Sturgeon, T. (2014). Explaining governance in global value chains: A modular theory-building effort. Review of International Political Economy, 21(1), 195-223. doi: https://doi.org/10.1080/09692290.2013.809596

Power, D. (2005). Supply chain management integration and implementation: a literature review. Supply Chain Management: An International Journal, 10(4), 252-263. doi: https://doi.org/10.1108/13598540510612721

Robson, I., and Rawnsley, V. (2001). Co-operation or coercion? Supplier networks and relationships in the UK food industry. Supply Chain Management, 6(1), 39-47. doi: https://doi.org/10.1108/13598540110384279 
Schwarz, G. (1978). Estimating the dimension of a model. The annals of statistics, 6(2), 461464. doi: https://doi.org/10.1214/aos/1176344136

Singh, P.J., and Power, D. (2009). The nature and effectiveness of collaboration between firms, their customers and suppliers: a supply chain perspective. Supply Chain Management: An International Journal, 14(3), 189-200. doi: https://doi.org/10.1108/13598540910954539

Skinner, W. (1966). Production under Pressure. Harvard Business Review, 44(6), 139-145.

Vachon, S., and Klassen, R. D. (2006). Extending green practices across the supply chain: the impact of upstream and downstream integration. International Journal of Operations and Production Management, 26(7), 795-821. doi: https://doi.org/10.1108/01443570610672248

Walton, S. V., Handfield, R. B., and Melnyk, S. A. (1998). The green supply chain: integrating suppliers into environmental management processes. International Journal of Purchasing and Materials Management, 34(1), 2-11. doi: https://doi.org/10.1111/j.1745-493X.1998.tb00042.x

Watts, C. A., and Hahn, C. K. (1993). Supplier development programs: an empirical analysis. Journal of Supply Chain Management, 29(2), 10-17. doi: https://doi.org/10.1111/j.1745-493X.1993.tb00002.x

Wernerfelt, B. (1984). A resource-based view of the firm. Strategic management journal, 5(2), 171-180. doi: https://doi.org/10.1002/smj.4250050207

Zhao, L., Huo, B., Sun, L., and Zhao, X. (2013). The impact of supply chain risk on supply chain integration and company performance: a global investigation. Supply Chain Management: An International Journal, 18(2), 115-131. doi: https://doi.org/10.1108/13598541311318773 


\section{Appendix}

Questions used to identify governance structures:

Indicate the effort put in the last 3 years into implementing, and the current level of implementation of, action programs related to external integration:

\section{Current level of implementation}

\begin{tabular}{|c|c|c|c|c|c|}
\hline & \multicolumn{3}{|c|}{ None } & \multicolumn{2}{|c|}{ High } \\
\hline $\begin{array}{l}\text { production plans, order tracking and tracing, delivery status, } \\
\text { stock level) }\end{array}$ & 1 & 2 & 3 & 4 & 5 \\
\hline
\end{tabular}

Developing collaborative approaches with key suppliers (e.g.

supplier development, risk/revenue sharing, long-term

$\begin{array}{lllll}1 & 2 & 3 & 4 & 5\end{array}$

agreements)

Joint decision making with key suppliers (about product

design/modifications, process design/modifications, quality

$\begin{array}{lllll}1 & 2 & 3 & 4 & 5\end{array}$

improvement and cost control)

Sharing information with key customers (about sales forecast, production plans, order tracking and tracing, delivery status,

$\begin{array}{lllll}1 & 2 & 3 & 4 & 5\end{array}$
stock level)

Developing collaborative approaches with key customers (e.g. risk/revenue sharing, long-term agreements)

$\begin{array}{lllll}1 & 2 & 3 & 4 & 5\end{array}$

Joint decision making with key customers (about product design/modifications, process design/modifications, quality improvement and cost control)

How do you perceive the following characteristics of the environment in which your business unit operates?

\begin{tabular}{llllllll}
\hline Bargaining power of suppliers & Very weak & 1 & 2 & 3 & 4 & 5 & Very strong \\
\hline Bargaining power of customers & Very weak & 1 & 2 & 3 & 4 & 5 & Very strong \\
\hline
\end{tabular}


Question used to build the upgrading constructs

How has your manufacturing performance changed over the last three years?

Compared to three years ago the indicator has

\begin{tabular}{|c|c|c|c|c|c|}
\hline & $\begin{array}{l}\text { Decrease } \\
\text { (- 5\% or } \\
\text { worse) }\end{array}$ & $\begin{array}{l}\text { stayed about } \\
\text { the same } \\
(-5 \% /+5 \%)\end{array}$ & $\begin{array}{c}\text { slightly } \\
\text { increased } \\
(+5-+15 \%)\end{array}$ & $\begin{array}{l}\text { increased } \\
(+15-25 \%)\end{array}$ & $\begin{array}{c}\text { Strongly } \\
\text { increased } \\
(+25 \% \text { or } \\
\text { better })\end{array}$ \\
\hline Product quality and reliability & 1 & 2 & 3 & 4 & 5 \\
\hline New product introduction ability & 1 & 2 & 3 & 4 & 5 \\
\hline Product assistance/support & 1 & 2 & 3 & 4 & 5 \\
\hline $\begin{array}{l}\text { Customer service quality (e.g. } \\
\text { training, information, help-desk) }\end{array}$ & 1 & 2 & 3 & 4 & 5 \\
\hline $\begin{array}{c}\text { Workers' motivation and } \\
\text { satisfaction }\end{array}$ & 1 & 2 & 3 & 4 & 5 \\
\hline Health and safety conditions & 1 & 2 & 3 & 4 & 5 \\
\hline
\end{tabular}

Compared to three years ago the indicator has

\begin{tabular}{|c|c|c|c|c|c|}
\hline & $\begin{array}{l}\text { Increased } \\
\begin{array}{c}(+5 \% \text { or } \\
\text { worse })\end{array}\end{array}$ & $\begin{array}{l}\text { stayed about } \\
\text { the same } \\
(+5 \% /-5 \%)\end{array}$ & $\begin{array}{l}\text { slightly } \\
\text { decreased } \\
(-5 /-15 \%)\end{array}$ & $\begin{array}{l}\text { decreased } \\
(-15 /-25 \%)\end{array}$ & $\begin{array}{c}\text { strongly } \\
\text { decreased } \\
\text { (-25\% or } \\
\text { more) }\end{array}$ \\
\hline Unit manufacturing cost & 1 & 2 & 3 & 4 & 5 \\
\hline Ordering costs & 1 & 2 & 3 & 4 & 5 \\
\hline Manufacturing lead time & 1 & 2 & 3 & 4 & 5 \\
\hline $\begin{array}{l}\text { Materials, water and/or energy } \\
\text { consumption }\end{array}$ & 1 & 2 & 3 & 4 & 5 \\
\hline $\begin{array}{l}\text { Pollution emission and waste } \\
\text { production levels }\end{array}$ & 1 & 2 & 3 & 4 & 5 \\
\hline
\end{tabular}


Question used to investigate GVC participation

Where do you source the raw materials, parts/components, subassemblies/systems and sell the finished products/services resulting from your plant's dominant activity (answers should add up to $100 \%$ of the value):

\begin{tabular}{|c|c|c|}
\hline & Sourcing & Sales \\
\hline This country & _ & $\%$ \\
\hline Outside the country but within the continent ${ }^{1}$ & $-\%$ & - \% \\
\hline Outside this continent $^{1}$ & _ $\%$ & $\%$ \\
\hline Total & $100 \%$ & $100 \%$ \\
\hline
\end{tabular}

Questions used to build the controls variables

Origin (headquarters' country)

Size of the business unit (\# of employees in 2012):

How do you perceive the following characteristics of the environment in which your business unit operates?

\begin{tabular}{lrllllll} 
Market size & Declining rapidly & 1 & 2 & 3 & 4 & 5 & Growing rapidly \\
Rate of technological change & Very low & 1 & 2 & 3 & 4 & 5 & Very high \\
\hline
\end{tabular}

How would you describe the complexity of the dominant activity?

$$
\begin{array}{lllllll}
\text { Modular product design } & 1 & 2 & 3 & 4 & 5 & \text { Integrated product design }
\end{array}
$$

\section{What type of configuration has your manufacturing network?}

\begin{tabular}{|c|c|c|c|}
\hline $\begin{array}{c}\text { Stand-alone: only this } \\
\text { plant belongs to the }\end{array}$ & $\begin{array}{c}\text { Domestic: all the } \\
\text { plants are located in } \\
\text { company }{ }^{1}\end{array}$ & $\begin{array}{c}\text { Regional: all the plants } \\
\text { are located in one }\end{array}$ & $\begin{array}{c}\text { Global: plants are located } \\
\text { in different continents }\end{array}$ \\
$\square$ & $\square$ & continent $^{2}$ & $\square$ \\
\hline
\end{tabular}

If you selected this option you can skip to the end the questionnaire

${ }^{2}$ Referring to South America, North America, West Europe, East Europe, Middle East, Far East, Oceania, Africa. 